Vol. 7(4), pp. 135-139, April 2015

DOI: 10.5897/J VMAH2014. 0336

Artic le Number: ED4EA7A51215

ISSN 2141-2529

Copyright (c) 2015

Author(s) retain the copyright of this article

http://www.academic joumals.org/J VMAH
Journal of Veterinary Medicine and

Animal Health

\title{
The prevalence of gastro-intestinal parasites of carnivores in university zoological gardens in South West Nigeria
}

\author{
Adeniyi, I.C. ${ }^{1}$, Morenikeji, O.A. ${ }^{1 *}$ and Emikpe, B.O. ${ }^{2}$ \\ ${ }^{1}$ Parasitology unit, Department of Zoology, University of Ibadan, Oyo State, Nigeria. \\ ${ }^{2}$ Veterinary Pathology, University of Ibadan, Oyo State, Nigeria.
}

Received 12 October, 2014; Accepted 19 February 2015

\begin{abstract}
A survey of prevalence and intensity of gastro-intestinal parasites of carnivores in three university zoological gardens in South-West Nigeria was conducted. Faecal samples collected were analysed with flotation technique using a saturated solution of zinc sulfate as the floating solution, McMaster Egg Counting Technique and Petri Dish-Filter Paper Slant technique for larval recovery. Faecal examination revealed an overall infection prevalence of $49.1 \%$. The prevalence in University of Ibadan (UI) zoo was 23.7\%, 54.8\% in Obafemi Awolowo University (OAU) and 69.2\% in University of Ilorin (Unillorin) zoos. The gastrointestinal helminths identified include Ancylostoma sp., Ascaris sp., Baylisascaris sp., Toxascaris sp., Toxocara sp., Strongyloides sp. and Entamoeba sp. was the only protozoa encountered. Ascaris sp., had the highest prevalence of $22.6 \%$, followed by Ancylostoma sp. with a rate of $20.8 \%$. Baylisascaris sp., and Strongyloides sp. both had a prevalence rate of $13.2 \%$ each, while Entamoeba sp. yielded the lowest prevalence (3.8\%). Regular monitoring of parasitic diseases and the use of selective treatments would be effective for the control of the gastrointestinal helminths for the wellbeing of animals, safety of zoo keepers and tourists in the zoo.
\end{abstract}

Key words: Carnivores, gastrointestinal parasites, zoological gardens, South-West Nigeria.

\section{INTRODUCTION}

A zoological garden is a form of ex situ conservation, which primarily involves keeping wild animals alive outside their natural environment for aesthetic, educational, research and recreational purposes (Varadharajan and Pythal, 1999).

Nigeria is blessed with abundant wildlife species which need to be properly managed on a sustainable basis to prevent depletion (Opara et al., 2010), hence the need to adopt strict management of these resources.
Repopulation of endangered species and conservation of wild animals in wildlife parks and zoological gardens are management strategies (Ajibade et al., 2010). Parasites play a major role in the lives of animals, with effects ranging from negative impacts on host population size to the evolution of host behaviours to combat parasites. Parasitic diseases constitute one of the major challenges in wild animals in captivity (Adedokun et al., 2002; Emikpe et al., 2002; Singh et al., 2006; Emikpe et al. 
Table 1. Distribution of carnivorous animals at the three zoological gardens

\begin{tabular}{lcccc}
\hline CarnivorelZoo & U.I. & O.A.U & Uni-Ilorin & Total \\
\hline Lion (Panthera leo) & 8 & 6 & 6 & 20 \\
Stripped Hyaena (Hyaena hyaena) & 2 & 1 & 2 & 5 \\
Spotted Hyaena (Crocuta crocuta) & - & - & 2 & 2 \\
Jackal (Canis mesomelas) & 1 & - & - & 1 \\
Tibetan Fox (Vulpes ferrilata) & 1 & 1 & 2 & 4 \\
Common palm Civet (Paradoxurus hermaphroditus) & - & 2 & 1 & 3 \\
Total & 12 & 10 & 13 & 35 \\
\hline
\end{tabular}

2007).

In the wild, animals might have a natural resistance against parasitic infections or live mutually with their parasites (Borkovcova and Kopriva , 2005). Change in environment and living conditions from freedom to captivity influences the animals' ecology and might increase the susceptibility to parasitic infections (Goossensa et al., 2005; Singh et al., 2006). Many of these animals are exotic to the geographical location of the parks and zoo gardens where they are kept. So also, keeping animals in captivity aggregates a number of species of animals in close proximity. Proximity provides opportunity for the transmission of diseases or parasites to species which would not normally come in contact with such pathogens (Moudgil and Singla, 2013). Severe parasitoses can lead to blood loss, tissue damage, spontaneous abortion, congenital malformations and death (Adedokun et al., 2002; Emikpe et al., 2002; Despommier, 2003; Emikpe et al., 2007).

Another possibility of parasite transmission is when animals are moved from one enclosure to another, without proper parasite treatment. Mixing different species brings additional risks of parasitic infections (Goossensa et al., 2005). Zoological garden staff members have also been reported to play an important role in the transmission of parasites amongst animals in zoos, through their shoes, clothes, hands, food or with working tools (Adetunji, 2014; Otegbade and Morenikeji, 2014). Most of these parasites are zoonotic and pose a serious threat to human health (Kashid et al., 2003).

Carnivorous animals act as definitive hosts for many intestinal parasites, some of which are responsible for several zoonotic diseases like ancylostomosis, echinococcosis, gnathostomosis and toxocarosis (Schantz and Kramer, 1995; Eslami and Hosseini, 1998). Overgaauw (1997), further suggested close interaction between humans and carnivores as reasons for endemicity of these zoonotic parasites.

Inadequate information on diseases and parasites of zoo animals is a major limiting factor in the management of zoological gardens. Investigations into prevalence, geographical distribution, systematic and biology of parasites of zoo animals are important for planning and control of parasitoses. Hence, the need for a regular program of gastrointestinal parasite surveillance and measures of control based on correct diagnosis, effective treatment and proper prophylaxis to ensure sound health of zoo animals (Ajibade et al., 2010; Moudgil et al., 2014). This study aims to establish the profile of gastrointestinal parasites in carnivores in three zoos in Nigeria.

\section{MATERIALS AND METHODS}

\section{Study area}

This study was carried out in the zoological gardens of three Southwestern Universities in Nigeria: the University of Ibadan Zoological Garden (UI Zoo), Ibadan which lies on latitude $7^{\circ} 26^{\prime} \mathrm{N}$ and longitude $3^{\circ} 53^{\prime} \mathrm{E}$; Obafemi Awolowo University Biological gardens (OAU Zoo), lle Ife $\left(7.4667^{\circ} \mathrm{N}, 4.5667^{\circ} \mathrm{E}\right)$ and University of llorin Zoological Garden (UNILORIN Zoo), Ilorin (latitude $8^{\circ} 30$ and longitude $4^{\circ} 35^{\prime} \mathrm{E}$ ). The zoological gardens have several different sections and the animals are put in sections by species. Indoor and outdoor enclosures are cleaned on a routine basis with necessary prophylaxis. Animals are regularly dewormed in some zoos to curb parasitic infections. Natural features, such as branches, climbing structures, and platforms are used for enrichment of enclosures to promote animal well-being. Carnivore species, such as lions, are housed in large closed circuit enclosures for the safety of visitors and tourists (Table 1).

\section{Collection of samples and coprologic examination}

Fresh faecal samples were collected in triplicates from the carnivores between March, 2012 and May, 2012 to examine for gastrointestinal parasites. Samples were collected in plastic vials, which were clearly marked with the time and date of collection, species of the animal, and the animal's cage number. All samples were transported to the laboratory, and examined within $48 \mathrm{~h}$. The faeces were examined macroscopically for consistency, presence of blood, mucus, tapeworm proglottids and larval nematodes. Examination for parasite eggs and larvae was by standard methods. Qualitative egg identification was done by floatation technique using a saturated solution of zinc sulfate (703 g/l, specific gravity 1.18) as the floating solution, McMaster Egg Counting Technique for quantitative ova examination while larva culture was done using the petri dish- filter paper slant culture technique (modified Harada- Mori Technique) as described by Garcia (2001). Some quantity of each faecal sample was cultured for 10 days to harvest and identify helminth larvae (Soulsby, 1982). Larvae that emerged were subsequently recovered for identification using typical morphological features (Sloss et al., 1994 
Table 2. Prevalence of gastro-intestinal parasites in carnivorous animals in the zoological gardens

\begin{tabular}{|c|c|c|c|c|c|c|c|c|c|c|}
\hline Zoo & Animals & $\begin{array}{c}\text { Faecal } \\
\text { samples }\end{array}$ & $\begin{array}{l}\text { No and } \% \text { of } \\
\text { prevalence }\end{array}$ & $\begin{array}{c}\text { Ascaris sp } \\
(\%)\end{array}$ & $\begin{array}{c}\text { Toxascaris sp } \\
(\%)\end{array}$ & $\begin{array}{c}\text { Toxocara sp } \\
(\%)\end{array}$ & $\begin{array}{c}\text { Strongyloides sp } \\
(\%)\end{array}$ & $\begin{array}{c}\text { Ancylostoma sp } \\
(\%)\end{array}$ & $\begin{array}{c}\text { Bayliascaris sp } \\
(\%)\end{array}$ & $\begin{array}{c}\text { Entamoeba sp } \\
(\%)\end{array}$ \\
\hline \multirow{5}{*}{ U.I. } & Lion & 24 & - & - & - & - & - & - & - & - \\
\hline & Stripped Hyaena & 6 & $4(66.7)$ & - & - & - & - & $4(100)$ & - & - \\
\hline & Jackal & 5 & $5(100)$ & - & - & - & - & - & $5(100)$ & - \\
\hline & Fox & 3 & - & - & - & - & - & - & - & - \\
\hline & Total & 38 & $9(23.7)$ & - & - & - & - & $4(44.5)$ & $5(55.6)$ & - \\
\hline \multirow{5}{*}{ O.AU } & Lion & 18 & $10(55.6)$ & $5(50)$ & $3(10)$ & - & $2(20)$ & - & - & - \\
\hline & Striped Hyaena & 3 & $2(66.7)$ & - & - & - & - & $2(100)$ & - & - \\
\hline & Fox & 4 & $4(100)$ & - & - & $2(50)$ & - & - & $2(50)$ & - \\
\hline & Civet & 6 & $1(16.7)$ & - & - & - & - & - & - & $1(100)$ \\
\hline & Total & 31 & $17(54.8)$ & $5(29.4)$ & $3(17.6)$ & $2(11.8)$ & 2(11.8) & $2(11.8)$ & $2(11.8)$ & $1(5.9)$ \\
\hline \multirow{6}{*}{ UNILORIN } & Lion & 18 & $12(66.7)$ & - & $6(50)$ & $3(25)$ & $3(25)$ & - & - & - \\
\hline & Striped Hyaena & 6 & $6(100)$ & $4(66.7)$ & - & - & $2(33.3)$ & - & - & - \\
\hline & Spotted Hyaena & 6 & $6(100)$ & - & - & - & - & $5(83.3)$ & - & $1(16.7)$ \\
\hline & Civet & 3 & $3(100)$ & $3(100)$ & - & - & - & - & - & - \\
\hline & Fox & 6 & - & - & - & - & - & - & - & - \\
\hline & Total & 39 & 27 (69.2) & $7(25.9)$ & $6(22.2)$ & $3(11.1)$ & $5(18.5)$ & $5(18.5)$ & - & $1(3.7)$ \\
\hline TOTAL & & 108 & $53(49.1)$ & $12(22.6)$ & $9(17)$ & $5(9.4)$ & $7(13.2)$ & $11(20.8)$ & $7(13.2)$ & $2(3.8)$ \\
\hline
\end{tabular}

\section{Statistical analysis of data}

Descriptive statistical analysis was used to summarize the results as percentage, means and standard deviations and differences between the means were determined using the analysis of variance (ANOVA) at the $5 \%$ level of significance.

\section{RESULTS}

\section{Study population}

A total of 35 carnivorous animals of two families, Canidae and Felidae were present in the three zoological gardens (Table 1).

\section{Prevalence of helminth parasites in the zoological gardens}

Of all the faecal samples collected (108), 53 $(49.1 \%)$ were found infected. The prevalence of gastrointestinal parasites in the samples examined comprises UI - 23.7\%, OAU - $54.8 \%$, UNILORIN - $69.2 \%$ (Table 2). Ascaris sp. was found in $12(22.6 \%)$, Ancylostoma sp. in 11 (20.8\%), Baylisascaris sp. in 7 (13.2\%), Toxascaris sp. in $9(17 \%)$, Toxocara sp. in 5 (9.4\%), and Strongyloides sp. in 7 (13.2\%). None was found infected with tapeworms.

\section{Distribution of parasites in the zoo animals}

In UI Zoo, not all the animals sampled were infected. Infections were found only in some samples collected from hyaenas and jackal and these were infected with Ancylostoma sp. and Baylisascaris sp. respectively (Table 3 ). In OAU Zoo, parasites were identified in most samples, with Fox having the highest prevalence rate of 100\%. The foxes were infected with Toxocara sp. were infected with more types of parasites (Ascaris $\mathrm{sp}$, Toxascaris $\mathrm{sp}$ and Strongyloides $\mathrm{sp}$ ) even though their prevalence was not as high as 
Table 3. Parasite distribution in the faecal samples of the zoo animals studied

\begin{tabular}{|c|c|c|c|c|}
\hline & Animal & $\begin{array}{c}\text { No. of samples } \\
\text { collected }\end{array}$ & $\begin{array}{l}\text { No. of samples with } \\
\text { parasites (\%) }\end{array}$ & $\begin{array}{l}\text { Parasites discovered through Floatation Technique } \\
\text { (No of sample) }\end{array}$ \\
\hline & Lion & 24 & - & - \\
\hline \multirow[t]{6}{*}{ UI } & Stripped Hyena & 6 & $4(66.7)$ & Ancylostoma sp (4) \\
\hline & Jackal & 5 & $5(100)$ & Baylisascaris sp (5) \\
\hline & Fox & 3 & - & - \\
\hline & Total & 38 & $9(23.7)$ & - \\
\hline & Lion & 18 & $10(55.6)$ & Ascaris sp (5),Toxascaris sp (3), Strongyloides sp (2) \\
\hline & Stripped Hyena & 3 & $2(66.7)$ & Ancylostoma sp (2) \\
\hline \multirow[t]{5}{*}{ OAU } & Fox & 4 & $4(100)$ & Toxocara sp (2), Baylisascaris sp (2) \\
\hline & Civet & 6 & $1(16.7)$ & Entamoeba sp (1) \\
\hline & Total & 31 & $17(54.8)$ & - \\
\hline & Lion & 18 & $12(66.7)$ & Toxocara sp (3), Strongyloides sp (3), Toxascaris sp (6) \\
\hline & Stripped Hyena & 6 & $6(100)$ & Ascaris sp (4), Strongyloides sp (2) \\
\hline \multirow[t]{4}{*}{ UNILORIN } & Spotted Hyena & 6 & $6(100)$ & Ancylostoma sp (5) \\
\hline & Civet & 3 & $3(100)$ & Ascaris sp (3) \\
\hline & Fox & 6 & - & Entamoeba sp (1) \\
\hline & Total & 39 & $27(69.2)$ & - \\
\hline
\end{tabular}

that of the foxes.

In University of Ilorin Zoo, infections were found in some samples collected from all the animals except the fox. All the stripped and spotted Hyenas, and Civet sampled were $100 \%$ infected, but the lions were infected with more types of parasites (Table 3).

\section{Intensity of gastrointestinal parasites in the carnivorous animals}

There was no significant difference in the intensity of Ancylostoma sp (100.0 \pm 0.50$)$ and Baylisascaris $\mathrm{sp}(83.0 \pm 0.33)$ discovered in $\mathrm{Ul}$ $(P>0.05)$, also, no significant difference in the intensity of the different parasites (Ascaris sp 90.0 \pm 0.19 , Toxascaris sp $66.7 \pm 0.17$; Strongyloides $s p 100.0 \pm 0.50)$ found in OAU zoo. The number of Toxacara sp $(25.0 \pm 0.25)$ found in OAU was significantly lower than other parasites discovered $(P<0.05)$.

\section{DISCUSSION}

This study showed the types, prevalence and intensity of gastrointestinal parasites in carnivorous animals in three strategic zoos in South West Nigeria. Ascaris sp, Toxascaris sp, Strongyloides $\mathrm{sp}$, Baylisascaris sp, Ancylostoma sp, Toxacara $\mathrm{sp}$ and Entamoeba sp were the parasites identified in different carnivores. All the parasites recovered from the various species of carnivores were also earlier reported in Nigerian captive animals (Parsani et al., 2001; Ajibade et al., 2010; Opara et al., 2010).

The observed total prevalence of $49.1 \%$ is in agreement with the studies of Atanaskova et al. (2011) in Skopje, Macedonia and Lalosevic et al. (2007) in Palic Zoo in Serbia. However, prevalence observed in the present study was lower than that reported by Ajibade et al. (2010) and Opara et al. (2010) with prevalence rates of 62.5 and $61.5 \%$ respectively. Among individual parasitic infections, the study revealed infection of 22.6\% for Ascaris sp, 13.2\% for Strongyloides sp, $20.8 \%$ for Ancylostoma sp and $3.8 \%$ for Entamoeba sp. The observation was in agreement with the findings of Opara et al. (2010) who recorded a higher prevalence of helminthes (82.2\%) 
and protozoan (17.8\%) (Entamoeba and Giardia species) parasites in zoo captive animals.

This study also showed that parasitic diseases are common to zoo carnivores in countries of warm and tropical climates due to the factors that favor the development of parasites such as light, temperature and humidity (Magona and Musisi, 1999; Opara et al., 2010). Attendants cleaning the cages and enclosures of these animals could act as a vehicle (formite) for cross transmission. Also, the animals serve as potential reservoirs that could transmit gastrointestinal protozoans and helminths to zoo keepers and possibly to visitors.

This study further shows the need for a well-adjusted anthelmintic program, such as early season treatments to prevent infection in wildlife species under captivity, regular passive surveillance for parasitic infections and effective treatment programs.

\section{Conflicts of interest}

The authors declare that they have no conflicts of interest.

\section{REFERENCES}

Adedokun OA, Adedokun RAM, Emikpe BO, Ohore OG, Oluwayelu DO, Ajayi OL (2002). Concurrent fatal helminthosis and Balantidosis in red monkey (Erythrocebus patas) in Ibadan, Nigeria. Niger. Vet. J. 23(2):56-59.

Adetunji VE (2014). Prevalence of gastro-intestinal parasites in primates and their keepers from two zoological gardens in Ibadan, Nigeria. Sokoto J. Vet. Sci. 12(2):25-30

Ajibade WA, Adeyemo OK, Agbede SA (2010). Coprological survey and Invectory of animals at Obafemi Awolowo University and University of Ibadan zoological gardens. World J. Zool. 5(4):266-271.

Atanaskova E, Zoran K, Jovana S, Goran N (2011). Endoparasites in wild animals at the zoological garden, Skopje, Macedonia. J. Threat. Taxa 3(7):1955-1958.

Borkovcova M, Kopriva J (2005). Parasitic Helminthes of Reptiles (Reptilia), South Moravia, Czech Republic. Parasitol. Res. 95:77-78.

Despommier D (2003). Toxocariasis: Clinical aspects, epidemiology, medical ecology, and molecular aspects. Clin. Microbiol. Rev. $16: 265-272$

Emikpe BO, Ayoade GO, Ohore OG, Olaniyan OO, Akusu MO (2002). Fatal trichuriosis in a captive baboon (Papio anubis) in Ibadan Nigeria: A case report. Trop. Vet 20 (1):36-39

Emikpe BO, Adeniran GA, Alaka OO, Ohore OG, Antia RE, Ajayi OL, Omobowale OT (2007). Valvular endocarditis in a captive monkey in Ibadan, Nigeria: a case report. Niger. Vet. J. 28 (3):49-52
Eslami A, Hosseini SH (1998). Morphological characteristics of Echinococcus granulosus of sheep, cattle and camel origin in Iran. J. Helminthol. 72:337- 341.

Garcia LS (2001). Diagnostic Medical Parasitology, 4th ed. ASM Press, Washington, D. C. pp. 786- 795.

Goossensa E, Dornya P, Boomker J, Vercammen F, Vercruysse T (2005). A 12-month survey of the gastro-intestinal helminths of antelopes, gazelles and giraffes kept at two zoos in Belgium. Vet. Parasitol. 127:303-312.

Kashid KP, Shrikhande GB, Bojne GR (2003). Incidence of gastrointestinal helminths of captive wild animals at different locations. Zoos' Print J. 18(3):1053-1054.

Lalosevic V, Lalosevic D, Bobos S, Spasojevic L (2007). Nalaz crevnih parazita kod zivotinja u zooloskom vrtu 'Palic', Savremena poljoprivreda. 56(3-4):98-102.

Magona JW, Musisi G (1999). Prevalence and infections levels of gastrointestinal nematodes in Ugandan goats in different agro climatic zones. Bull. Anim. Health. Prod. Afr. 47:49-56.

Moudgil AD, Singla LD (2013). Role of neglected wildlife disease ecology in emergence and resurgence of parasitic diseases. Trends Parasitol. Res. 2(2):18-23.

Moudgil AD, Singla LD, Singh MP (2014). First report on molecular identification and fenbendazole resistance against Baylisascaris transfuga infection in Melursus ursinus (Sloth bear). Helminthologia 51(4):262-268

Opara MN, Osuji CT, Opara JA (2010). Gastrointestinal parasitism in captive animals at the Zoological Garden Nekede, Owerri, Southeast Nigeria. Rep. Opin. 2(5):21-28.

Otegbade AC, Morenikeji OA (2014). Gastrointestinal parasites of birds in zoological gardens in South-West Nigeria. Trop. Biomed. 31(1):5462.

Overgaauw PA. (1997). Prevalence of intestinal nematodes of dogs and cats in the Netherlands. Vet. Quart. 19 (1):14-17.

Parsani HR, Momin RR, Maradia MG, Veer S (2001). A Survey of gastrointestinal parasites of captive animals at Rajkot Municipal Corporation Zoo, Rajkot, Gujarat. Zoo's Print J. 16(10):604-606.

Schantz PM, Kramer MH (1995). Larval cestode infections: cysticercosis and echinococcosis. Curr. Opin. Infect. Dis. 8:342-350.

Singh P, Gupta MP, Singla LD, Singh N, Sharma DR (2006a). Prevalence and chemotherapy of gastrointestinal helminthic infections in wild carnivores in Mahedra Choudhury Zoological Park, Punjab. J. Vet. Parasitol. 20:17-23.

Singh P, Gupta MP, Singla LD, Sharma S, Sandhu BS, Sharma DR (2006b). Parasitic infections in wild herbivores in the Mahendra Choudhury Zoological Park, Chhat Bir, Punjab. Zoo's Print J. 21(11):2459-2461.

Sloss MW, Kemp RL, Zajac AM (1994). Veterinary clinical parasitology. 6th Ed. Iowa State University Press, Ames.

Soulsby EJL (1982). Helminthes, arthropods and protozoa of domesticated animals, 7th edition. Bailliere Tindall, London, UK.

Varadharajan A, Pythal C (1999). A preliminary investigation on the parasites of wild animals at the Zoological Garden, Thiruvananthapuram, Kerala. Zoo's Print J. 14(312):159-164. 